\title{
PERBEDAAN PERSEPSI KONSUMEN ATAS FAKTOR PENENTU TEMPAT BELANJA PADA INDOMARET DAN ALFAMART \\ (Studi Kasus pada Masyarakat Griya Martubung Kelurahan Besar Kec. Medan Labuhan)
}

\author{
Elisabeth \\ Universitas Katolik Santo Thomas Medan Jl. Setia Budi No. 479F, 20132, Indonesia \\ e-mail: Elisabeth081966@gmail.com
}

\begin{abstract}
The purpose of this study was to analyze differences in consumer perceptions of the determinants of shopping for products, location, price, convenience of shopping, advertising, and employee services found at Indomaret and Alfamart and to analyze several types of factors that were superior to Indomaret and Alfamart Other retailers are located in Griya Martubung, Kelurahan Besar, Medan Labuhan District. Benefits This research provides information material to Indomaret and Alfamart parties about differences in consumer perceptions of the determinants of shopping places regarding products, location, price, convenience of shopping, advertising, and employee services. For other researchers it can be used as a reference in conducting studies or research with the same subject matter as well as input for parties directly concerned with this research. The number of samples is 200 respondents, the method of collecting data through questionnaires and documentation, the variables studied about consumer perceptions of the determinants of shopping about products, location, price, convenience of shopping, advertising, and employee services owned by Indomaret and Alfamart, methods of data analysis with chi-square. The results showed that there were differences in Indomaret consumer perceptions with Alfamart consumer perceptions on location indicators, the completeness of the products offered, prices and advertisements. The difference mentioned above is that Indomaret is superior compared to Alfamart. While in terms of convenience, shopping and services provided have a significant difference in the sense that Alfamart is superior to Indomaret. Based on the results of testing the hypothesis by Chi-Square $(\chi 2)$, it is known that there is a significant difference between the perceptions of Indomaret consumers and Alfamart consumer perceptions. This is indicated by the value of itung 2 count $\left(\chi^{2}=61.72\right)>x^{2}$ table (tabel2 table $=11.07$ ). For the management of Indomaret, it is better to improve policies related to convenience in shopping, such as ease of consumer mobility when shopping and service quality. Meanwhile, Alfamart should evaluate policies related to products, location, price and advertising.
\end{abstract}

Keywords: Product, Location, Price, Advertisement, Comfort and Service

\section{PENDAHULUAN}

Di era globalisasi sekarang ini kegiatan bisnis khususnya pemasaran dari waktu ke waktu semakin meningkat. Banyak sekali perusahaan yang berusaha memenangkan persaingan dengan cara memanfaatkan peluang bisnis yang ada dan berusaha menerapkan strategi pemasaran yang tepat dalam rangka menguasai pasar. Pemasaran adalah proses sosial dimana individu dan kelompok mendapat apa yang mereka butuhkan dan inginkan dengan menciptakan dan mempertahankan produk dan nilai dengan individu atau kelompok lainya (Irawan,2001:10).

Memilih toko adalah proses interaksi antara strategi pemasaran pengecer dan karateristik individual dan situasional dari pembeli proses ini di gambarkan oleh diagram keputusan pembelian pada umumnya. Karateristik individual seperti gaya hidup menyebabkan pandangan umum tentang aktivitas yang terlibat dalam perilaku berbelanja dan pencarian. Jika pengalaman masa lalu memuaskan, maka pilihan akan bersifat kebiasaan. Kecuali jika faktor-faktor lain berubah sejak kunjungan terahir (Engel,1995: 252).

Dalam berbelanja konsumen akan memiliki suatu citra dari berbagai toko. Konsumen memilah-milah atau membanding-bandingkan karateristik toko yang di rasakan dengan 


\section{Volume 18 Nomor 2}

kriteria evaluasi dari pelanggan inti.Atribut yang menyolok atau determinan biasanya masuk dari kategori berikut ini : (1) lokasi, (2)sifat dan kualitas pengamanan, (3) harga, (4) iklan dan promosi, (5) personel penjualan,, (6) atribut fisik toko, (7) sifat pelanggan toko, (8) atmosfer toko dan (9) pelayanan dan kepuasan setelah transaksi (Engel,1995:157). Namun di sini peneliti hanya mengambil enam komponen yang paling utama, yang dirasa memiliki pengaruh paling besar dalam menilai citra toko yaitu lokasi, pelayanan, kelengkapan produk yang ditawarkan, harga, iklan, dan kenyamanan berbelanja.

Di Indonesia terdapat beberapa merek minimarket diantaranya adalah Circle K, Alfamart, Indomaret. Persaingan minimarket di Indonesia sangat ketat dan dapat diihat dari persaingan antara 2 nama besar brand ritel minimarket yaitu Indomaret dan Alfamart. Persaingan antara Indomaret dan Alfamart sangat ketat, kedua brand ritel ternama ini terus bertarung mengerahkan semua kekuatan, kecerdikan dan strategi. Indomaret dimiliki oleh PT Indomarco Prismatama (IP). Alfamart dimiliki oleh PT. Sumber Alfaria Trijaya Tbk. (Alfamart/Perseroan).

Secara teoritis keputusan pembelian yang di lakukan konsumen terhadap barang yang di tawarkan sangat di pengaruhi harga, produk, pelayanan, lokasi perusahaan atau toko (Kotler, 1997: 165). Namun kenyataanya bahwa meski minimarket memiliki karateristik dan strategi yang hampir sama satu dengan yang lainya, kenyataananya dapat memiliki penjualan yang berbeda, seperti Indomart dan Alfamart yang biasanya berdampingan (Tajwini, Rofian, Majalah marketing: 2004).

Penelitian ini diharapkan dapat mengidentifikasi beberapa pengaruh perbedaan persepsi konsumen dari berbagai faktor pada Indomaret dan Alfamart, untuk meminimalkan kinerja yang baik di Indomaret dan Alfamart.

\section{TINJAUAN PUSTAKA}

\section{A. Pengertian Pemasaran Jasa}

Kegiatan pemasaran tidak terlepas dari fungsi-fungsi organisasi yang lain yang bertujuan menciptakan kepuasan pelanggan. Menurut Yazid (1999), pemasaran jasa adalah perencanaan yang bergerak dari focus pada transaksi menjadi hubungan jangka panjang dengan pelanggan. Sedangkan menurut Lupiyoadi (2001), pemasaran jasa adalah setiap tindakan yang ditawarkan oleh salah satu pihak ke pihak lain yang secara prinsip intangible dan tidak menyebabkan perpindahan kepemilikan apapun. Dari defenisi diatas dapat disimpulkan bahwa pemasaran jasa suatu tindakan yang ditawarkan pihak produsen kepada konsumen dalam arti jasa yang diberikan tidak dapat dilihat, dirasa, didengar atau diraba sebelum dibeli atau dikonsumsi.

\section{B. Karakteristik Jasa}

Berbagai riset dan literature manajemen dan pemasaran jasa mengungkapkan bahwa jasa memiliki empat karateristik yang membedakan barang dan jasa yang dinamakan paradigma IHIP : Intangibility, Heterogeneity, Inseparability dan Perishability (Lovelock dan Gummesson, dalam Fandy Tjiptono dan Gregorius Chandra, 2005).

1. Intangibility. Jasa bersifat Intangibility artinya jasa tidak dapat dilihat, dirasa, didengar, atau diraba sebelum dibeli dan dikonsumsi.

2. Heterogeneity. Jasa bersifat Heterogeneity karena merupakan non- standardized output artinya terbanyak variasi bentuk, kualitas dan jenis, tergantung pada siapa, kapan dan dimana jasa tersebut diproduksi.

3. Inseparability. Jasa bersifat Inseparability artinya jasa dijual terlebih dahulu kemudian baru diproduksi dan dikonsumsi pada waktu dan tempat yang sama.

4. Perishability. Jasa bersifat Perishability artinya jasa merupakan komoditas yang tidak tahan lama, tidak dapat disimpan untuk pemakaian ulang di waktu yang akan datang, dijual kembali atau dikembalikan. 


\section{Volume 18 Nomor 2}

Sedangkan menurut Griffin dalam Lupiyoadi (2001) karakteristik Jasa yaitu :

1. Intangibility (tidak berwujud). Jasa tidak dapat dilihat, dirasa, diraba, didengar, atau dicium sebelum jasa itu dibeli.

2. Unstorability. Jasa tidak mengenal persediaan atau penyimpanan dari produk yang telah dihasilkan.

3. Customization. Jasa juga sering kali di desain khusus untuk kebutuhan pelanggan, sebagaimana pada jasa asuransi dan kesehatan.

\section{Pengertian Kualitas Pelayanan}

Kualitas pelayanan dapat didefinisikan sebagai seberapa jauh perbedaan antara kenyataan dan harapan para pelanggan atas layanan yang mereka terim. Menurut Lewis \& Booms dalam Tjiptono \& Chandra (2005), kualitas pelayanan sebagai ukuran seberapa baik tingkat layanan yang diberikan mampu sesuai dengan harapan pelanggan. Sedangkan menurut Tjiptono (2001), kualitas pelayanan adalah tingkat keunggulan yang diharapkan dan pengendalian atas tingkat keunggulan tersebut untuk memenuhi keinginan pelanggan. Berdasarkan pendapat diatas, faktor utama yang mempengaruhi kualitas pelayanan yaitu, jasa yang diharapkan dan jasa yang dirasakan / dipersepsikan. Apabila jasa yang dirasakan sesuai dengan jasa yang diharapkan, maka kualitas pelayanan tersebut akan dipersepsikan memuaskan. Jika jasa yang dipersepsikan melebihi jasa yang diharapkan, maka kualitas jasa dipersepsikan sebagai kualitas ideal.

\section{Pengertian Persepsi}

Menurut Schiffman dan Kanuk (2000:146)“Perception is process by which an individuals selects, organizers, and interprets stimuli in to the a meaningfull and coherent picture of the world". Kurang lebihnya bahwa persepsi merupakan suatu proses yang membuat seseorang untuk memilih, mengorganisasikan, dan menginterpretasikan rangsangan-rangsangan yang diterima menjadi suatu gambaran yang berarti dan lengkap tentang dunianya. Sedangkan Kotler dan Amstrong (2008:174) mengemukakan bahwa dalam keadaan yang sama, persepsi seseorang terhadap suatu produk dapat berbeda- beda, hal ini disebabkan oleh adanya proses perceptual (berhubungan dengan/ransangan sensorik) yaitu atensi selektif, distorsi selektif dan retensi selektif.

Persepsi setiap orang terhadap suatu obyek akan berbeda-beda. Oleh karena itu persepsi memiliki sifat yang subyektif. Persepsi yang dibentuk seseorang terhadap sesuatu sangat dipengaruhi oleh pikiran dan lingkungannya. Proses pembentukan persepsi dapat dilihat sebagai berikut :

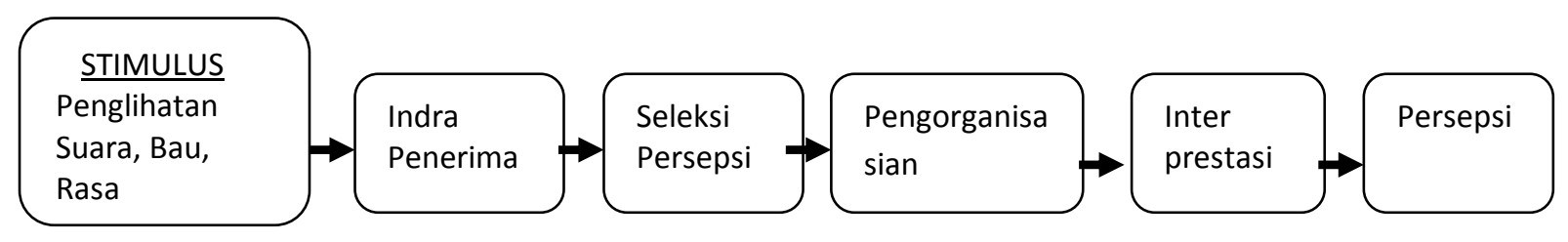

Gambar 1. Proses Persepsi

Sumber : J. Setiadi, Nugroho, 2003, "Perilaku Konsumen Konsep dan Implikasi untuk Strategi dan Penelitian Pemasaran". Jakarta: Kencana.

a. Seleksi persepsi. Seleksi persepsi terjadi ketika konsumen menangkap dan memilih stimulus berdasarkan psychological set (berbagai informasi yang ada didalam memorinya) yang dimiliki oleh konsumen tersebut. Dua proses yang sebenarnya terjadi dalam seleksi perceptual ini adalah perhatian (attention) dan seleksi itu sendiri.

b. Pengorganisasian Persepsi. Pengorganisasian persepsi berarti bahwa konsumen mengelompokkan informasi dari berbagai sumber kedalam pengertian yang menyeluruh 


\section{Volume 18 Nomor 2}

untuk memahami lebih baik dan bertindak atas pemahaman itu.

c. Interprestasi Persepsi. Interprestasi didasarkan pada pengalaman penggunaan suatu produk pada masa lalu dan pengalaman itu tersimpan dalam memori jangka panjang. Tahap inilah yang disebut persepsi konsumen terhadap obyek atau citra produk (product images) sebagai output dari penerimaan konsumen terhadap stimulus.

d. Komunikasi Pemasaran. Komunikasi pemasaran adalah upaya perusahaan dapat menyampaikan apa yang mereka tawarkan kepada konsumen dan konsumen dapat menerimanya dengan baik. Ada beberapa elemen komunikasi pemasaran yaitu periklanan, penjualan tatap muka (personal selling), kehumasan (public relation) dan pemasaran langsung. Beberapa tahap yang sering terjadi pada konsumen perusahaan eceran sebagai berikut:

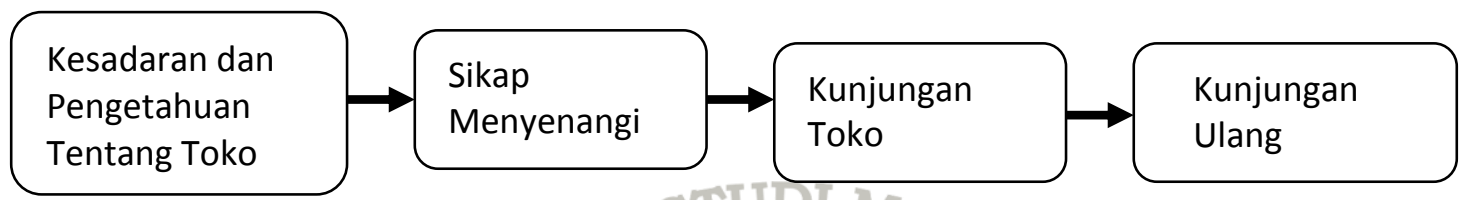

Gambar 2. Tahap Perilaku Konsumen Eceran

Sumber : Amir, M. Taufiq. 2005, Dinamika Pemasaran: Jelajahi \& Rasakan, Jakarta: PT. RajaGrafindo Persada.

Tujuan perusahaan melakukan komunikasi pemasaran adalah.

1. Untuk Positioning. Kesan umum atau persepsi harus diciptakan perusahaan dibenak pelanggan dan orang banyak sehingga perusahaan terlihat berbeda atau memiliki diferensiasi dengan perusahaan lain.

2. Untuk peningkatan penjualan. Merupakan tujuan perusahaan yang sifatnya adalah untuk jangka pendek yaitu untuk mendapatkan laba.

Peritel atau pengecer adalah pengusaha yang menjual barang atau jasa secara eceran kepada masyarakat sebagai konsumen (Hendri Maaruf,2005:71). Peritel perorangan atau peritel kecil memiliki jumlah gerai bervariasi, mulai dari satu gerai hingga beberapa gerai. Gerai-gerai dari peritel kecil terdiri atas dua macam, yaitu gerai modern dan tradisional

1. Gerai tradisional. Gerai tradisional adalah geraí yang telah lama beroperasi di negeri ini berupa: warung, toko, dan pasar. Warung biasanya berupa bangunan sederhana yang permanen (tembok penuh) semi permanen (tembok setinggi 1 meter di sambung papan sebagai dinding), atau dinding kayu seutuhnya.

2. Gerai modern. Gerai modern mulai beroperasi awal 1960-an di Jakarta, arti modern di sini adalah penataan barang menurut keperluan yang sama di kelompokan di bagian yang sama yang dapat dilihat dan diambil langsung oleh pembeli, penggunaan alat pendingin udara, dan adanya pramuniaga profesional

\section{E. Minimarket}

Minimarket adalah toko swalayan yang hanya memiliki satu atau dua mesin register (http// www.sinarharapan.co.id). Sedang menurut Hendri ma'aruf (2005:76) yang di sebut minimarket biasanya luas ruanganya adalah antar $50 \mathrm{~m}^{2}$ sampai $200 \mathrm{~m}^{2}$ serta berada pada lokasi yang mudah dijangkau konsumen. Mini market mengisi kebutuhan masyarakat akan warung yang berformat modern. dengan mini market, belanja sedikit di tempat yang dekat dan nyaman terpenuhi, perilaku konsumen yang menyukai tempat belanja bersih, sejuk, dan tertata rapi membuat minimarket menjadi lebih unggul dari warung dan toko.

Perusahaan yang pertama kali menggunakan format minimarket sebagai strategi bisnis di Indonesia adalah PT. Indomarco Prismatama yang pada tahun 1988 mendirikan minimarketnya yang pertama. Perusahaan lain yang juga mengoperasikan minimarket adalah 


\section{Volume 18 Nomor 2}

Alfaria Trijaya yang pada tahun 2004 telah memiliki 923 gerai dengan nama alfamart dan merencanakan mengembangkan menjadi 1800 unit di seluruh Indonesia tahun 2005 (http//www.kontan-online.com Inc: 2004).

\section{METODE PENELITIAN}

\section{A. Populasi dan Sampel}

Populasi dalam penelitian ini, seluruh masyarakat Griya Martubung, Kelurahan Besar Kecamatan Medan Labuhan. Teknik pengambilan sampel dengan Teknik Cluster Sampling adalah dimana pemilihannya mengacu pada kelompok bukan pada individu. Cara seperti ini dilakukan apabila tidak terdapat atau sulit menentukan/menemukan kerangka sampel, meski dapat juga dilakukan pada populasi yang kerangka sampelnya sudah ada. Pengambilan sampel dengan cara Teknik Cluster Sampling dilakukan pada populasi yang bersifat terbatas. Dalam penelitian ini, peneliti menetapkan jumlah sampel 200 orang.

\section{B. Operasionalisasi Variabel}

Operasionalisasi variabel dalam penelitian ini yaitu :.

1. Produk adalah segala sesuatu yang dapat ditawarkan ke pasar untuk mendapatkan perhatian, dibeli, digunakan, atau dikonsumsi yang dapat memuaskan keinginan atau kebutuhan.

2. Lokasi . Lokasi/ Tempat adalah dimana suatu usaha atau aktivitas usaha dilakukan".

3. Harga. adalah sejumlah uang yang dibebankan atas suatu produk atau jasa, atau jumlah dari nilai yang ditukar konsumen atas manfaat-manfaat karena memiliki atau menggunakan produk atau jasa tersebut.

4. Iklan. yaitu kegiatan memberitahukan atau menginformasikan suatu hal, barang, atau jasa melalui media massa baik online maupun ofline.

5. Kenyamanan . adalah suatu keadaan telah terpenuhinya kebutuhan dasar manusia yang bersifat individual dan holistik.

6. Pelayanan. Pelayanan ialah menolong untuk menyediakan segala sesuatu yang diperlukan oleh orang lain diataranya adalah pembeli.

\section{Teknik Pengumpulan Data}

Teknik pengumpulan data yang digunakan dalam penelitian ini adalah:

1. Kuesioner, dilakukan dengan membagikan angket kepada responden

2. Teknik dokumentasi, dilakukan dengan mengumpulkan data yang sudah diolah sebelumnya dari Indomaret dan Alfamart.

\section{Teknik Analisis}

Metode analisis data yang digunakan dalam penelitian yaitu teknik analisis Chi Square. Uji chi-square dirumuskan sebagai berikut :

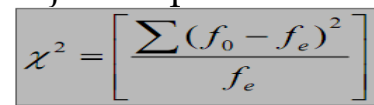

Keterangan :

$\chi^{2}=$ Nilai chi-kuadrat

$\mathrm{f}_{\mathrm{e}}=$ Frekuensi yang diharapkan

$\mathrm{f}_{\mathrm{o}}=$ Frekuensi yang diperoleh/diamati

\section{HASIL DAN PEMBAHASAN}

Indomaret merupakan jaringan minimarket yang menyediakan kebutuhan pokok dan kebutuhan sehari-hari yang dikelola oleh PT. Indomarco Prismatama. Sasaran pemasaran Indomaret adalah konsumen semua kalangan masyarakat, lokasi gerai yang strategis dimaksudkan untuk memudahkan Indomaret melayani sasaran demografinya yaitu 


\section{Volume 18 Nomor 2}

keluarga. Sistem distribusi dirancang seefisien mungkin dengan jaringan pemasok yang handal dalam menyediakan produk terkenal dan berkualitas serta sumber daya manusia yang kompeten,. Indomaret berupaya meningkatkan pelayanan dan kenyamanan belanja konsumen dengan menerapkan sistem check out yang menggunakan scanner di setiap kasir dan pemasangan fasilitas pembayaran Debit BCA. Budaya yang di terapkan dalam tubuh perusahaan Indomaret adalah dalam bekerja kami menjunjung tinggi nilai-nilai:

a. Kejujuran, kebenaran dan keadilan

b. Kerja sama tim

c. Kemajuan melalui inovasi yang ekonomis

d. Kepuasan pelanggan (sumber www.Indomaret.co.id)

PT Sumber Alfaria Trijaya (SAT) atau Alfamart merupakan perusahaan nasional yang bergerak dalam bidang perdagangan umum dan jasa eceran yang menyediakan kebutuhan pokok dan sehari-hari. Alfamart dapat dimiliki masyarakat luas dengan cara kemitraan.

Badan Usaha

Pemegang Saham

Didirikan

: PT Sumber Alfaria Trijaya

Jumlah Toko

: HM Sampoerna dan Alfa Group

: 27Juni 1999

\section{: Lebih dari 1400}

Sedangkan misinya adalah:

1. Memberikan kepuasan kepada pelanggan/konsumen dengan berfokus pada produk dan pelayanan yang berkualitas unggul.

2. Selalu menjadi yang terbaik dalam segala hal yang dilakukan dan selalu menegakkan tingkah laku/etika bisnis yang tertinggi.

3. Ikut berpartisipasi dalam membangun negara dengan menumbuh- kembangkan jiwa wiraswasta dan kemitraan usaha.

4. Membangun organisasi global yang terpercaya, tersehat dan terus bertumbuh dan bermanfaat bagi pelanggan, pemasok, karyawan, pemegang saham dan masyarakat pada umumnya.

\section{A. Responden Menurut Jenis Kelamin}

Berdasarkan hasil penelitian yang telah dilakukan, data yang didapat dari penyebaran angket diperoleh data jenis kelamin responden yang ditunjukan pada tabel berikut:

Tabel 1 Karateristik Responden Menurut Jenis Kelamin

\begin{tabular}{|l|c|c|c|}
\hline No & Jns kelamin & Jml responden & $\%$ \\
\hline 1. & Pria & 73 orang & $36 \%$ \\
2. & Wanita & 127 orang & $64 \%$ \\
\hline
\end{tabular}

Sumber : Data primer diolah, tahun 2017

Pada tabel di atas menunjukan, bahwa yang berbelanja di Indomaret dan Alfamart lebih dominan kaum wanita daripada laki-laki.

Berdasarkan hasil penelitian yang telah dilakukan, data yang didapat dari penyebaran angket diperoleh data usia responden yang ditunjukan tabel berikut:

Tabel 2 Karateristik Responden Menurut Usia

\begin{tabular}{|l|l|l|l|}
\hline No & Usia & Jumlah responden & $\%$ \\
\hline
\end{tabular}




\begin{tabular}{|c|c|c|c|}
\hline 1. & Kurang dari 20 tahun & 20 orang & $10 \%$ \\
\hline 2. & 20thn - 30thn & 60 orang & $30 \%$ \\
\hline 3. & 31thn - 40thn & 64 orang & $32 \%$ \\
\hline 4. & 41thn - 50thn & 30 orang & $15 \%$ \\
\hline 5. & lebih dari 51 & 26 orang & $13 \%$ \\
\hline
\end{tabular}

Sumber : Data primer diolah, tahun 2017

Pada tabel di atas menunjukan, bahwa yang berbelanja di Indomaret dan Alfamart lebih dominan yang berusia 31 tahun -40 tahun.

\section{B. Perhitungan menggunakan uji- Chi- Square $\left(x^{2}\right)$}

Langkah - langkah Pengujian :

1. Rumuskan Hipotesis nihil (Ho) dan alternatif (Ho)

Ho $: \chi^{2}=0$ Tidak ada perbedaan

$\mathrm{H} 1: \chi^{2} \neq 0$ Ada perbedaan

2. Buat Tabel Kontingensi

Tabel kontingensi berbentuk $2 \times 6$ ( 2 baris dan 6 kolom). Setiap kotak disebut sel, setiap sebuah kolom berisi sebuah subvariabel, setiap sebuah baris berisi sebuah subvariabel.

Tabel 3. Frekuensi hasil pengamatan

\begin{tabular}{|l|c|c|c|c|c|c|c|}
\hline \multirow{2}{*}{$\begin{array}{l}\text { Jenis } \\
\text { Minimarket }\end{array}$} & Produk & Lokasi & Harga & Kenyamanan & Iklan & Pelayanan & Total \\
\cline { 2 - 8 } & fo & fo & Fo & fo & fo & fo & fo \\
\hline Indomaret & 600 & 550 & 850 & 900 & 756 & 730 & 4393 \\
\hline Alfamart & 800 & 450 & 700 & 800 & 637 & 698 & 4085 \\
\hline Total & 1400 & 1000 & 1550 & 1700 & 1443 & 1385 & 8478 \\
\hline
\end{tabular}

3. Cari nilai Frekuensi yang Diharapkan (fe) fe untuk setiap sel $=$ (Total Baris) $($ Total Kolom $)$ Total Keseluruhan

4. Perhitungan uji-Chi-Square

Tabel 4. Perhitungan uji-Chi-Square

\begin{tabular}{|c|c|c|c|c|c|c|c|c|c|}
\hline \multirow{2}{*}{$\begin{array}{l}\text { Jenis } \\
\text { Minimarket }\end{array}$} & \multicolumn{2}{|c|}{ Produk } & \multicolumn{2}{|c|}{ Lokasi } & \multicolumn{3}{|c|}{ Harga } & \multicolumn{2}{|c|}{ Kenyamanan } \\
\hline & Fo & $\mathbf{F e}$ & fo & $\mathrm{fe}$ & Fo & & fe & fo & fe \\
\hline Indomaret & 600 & 725 & 550 & 518 & & 850 & 803 & 900 & 881 \\
\hline \multirow[t]{2}{*}{ Alfamart } & 800 & 675 & 450 & 482 & & 700 & 747 & 800 & 819 \\
\hline & 1400 & 1400 & 1000 & 1000 & & 1550 & 1550 & 1700 & 1700 \\
\hline \multirow{2}{*}{$\begin{array}{l}\text { Jenis } \\
\text { Minimarket }\end{array}$} & \multicolumn{3}{|c|}{ Iklan } & \multicolumn{4}{|c|}{ Pelayanan } & \multicolumn{2}{|c|}{ Total } \\
\hline & \multicolumn{2}{|l|}{ fo } & $\mathrm{Fe}$ & \multicolumn{2}{|l|}{ fo } & \multicolumn{2}{|l|}{$\mathrm{fe}$} & fo & $\mathrm{Fe}$ \\
\hline Indomaret & & 756 & 748 & & 730 & & 717 & 4393 & 4393 \\
\hline \multirow[t]{2}{*}{ Alfamart } & & 637 & 695 & & 698 & & 667 & 4085 & 4085 \\
\hline & & 1443 & 1443 & & 385 & & 1385 & 8478 & 8478 \\
\hline
\end{tabular}

5. Hitung nilai Chi-Square $\left(\chi^{2}\right)$

$$
\begin{aligned}
\chi^{2}= & (600-725)^{2} / 725+(550-518)^{2} / 518+(850-803)^{2} / 803+(900-881)^{2} / 881+ \\
& (756-748)^{2} / 748+(730-717)^{2} / 717+(800-675)^{2} / 675+(450-482)^{2} / 482+ \\
& (700-747)^{2} / 747+(800-819)^{2} / 819+(637-695)^{2} / 695+(698-667)^{2} / 667 \\
\chi^{2}= & 61.72
\end{aligned}
$$

6. Tentukan kriteria pengujian 


\section{Volume 18 Nomor 2}

- Jika $\chi^{2}$ hitung $\leq \chi^{2}$ tabel, maka Ho diterima.

- Jika $\chi^{2}$ hitung $>\chi^{2}$ tabel, maka Ho ditolak.

7. Tentukan nilai $\chi 2$ Tabel

- $\quad$ Taraf signifikansi $(a)=0,05$

- $\mathrm{Df}=($ Baris -1$)($ Kolom -1$)=(2-1)(6-1)=5$

- $x^{2}$ Tabel $=11.07$

8. Bandingkan $\chi^{2}$ hitung dengan $\chi^{2}$ tabel

$\chi^{2}$ hitung $=61.72 \geq \chi^{2}$ Tabel $=11.07$ maka Ho ditolak dan H1 diterima, berarti ada perbedaan persepsi konsumen atas faktor penentu tempat belanja mengenai produk, lokasi, harga, kenyamanan berbelanja, iklan, dan pelayanan karyawan yang dimiliki oleh Indomaret dan Alfamart

\section{KESIMPULAN}

Berdasarkan hasil pembahasan dapat diambil beberapa kesimpulan yaitu :

1. Ada perbedaan persepsi konsumen Indomaret dengan persepsi konsumen Alfamart pada indikator lokasi, kelengkapan produk yang ditawarkan, harga dan iklan. Perbedaan yang dimaksudkab di atas bahwa Indomaret lebih unggul di bandingkan dengan Alfamart. Sedangkan dari segi kenyamanan berbelanja dan pelayanan yang diberikan mempunyai perbedaan yang signifikan dalam arti Alfamart lebih unggul dibandingkan dengan Indomaret .

2. Berdasarkan hasil pengujian hipotesa dengan Chi-Square $\left(\chi^{2}\right)$ diketahui bahwa terdapat perbedaan yang signifikan antara persepsi konsumen Indomaret dengan persepsi konsumen Alfamart. Hal ini ditunjukkan dengan nilai $\chi^{2}$ hitung $\left(\chi^{2}=61.72\right)>\chi^{2}$ tabel $\left(\chi^{2}\right.$ tabel $\left.=11,07\right)$.

\section{DAFTAR PUSTAKA}

Amir, M. Taufiq. 2005, Dinamika Pemasaran: Jelajahi \& Rasakan, . Jakarta: PT. RajaGrafindo Persada.

Basu Swastha. 2002, Manajemen Pemasaran. Edisi Kedua. Cetakan Kedelapan. Jakarta: Penerbit Liberty

Fandy Tjiptono,2000, Manajemen Jasa, Andi Offset, Yogyakarta. 2001, Strategi Bisnis dan Manajemen, Andi Offset, Yogyakarta.

Fandi Tjiptono dan Gregorius Candra .2005. Service, Quality, and Satisfaction. Yogyakarta: Andi Offset.

J. Setiadi, Nugroho, 2003, "Perilaku Konsumen Konsep dan Implikasi untuk Strategi dan Penelitian Pemasaran". Jakarta: Kencana.

Kolcaba, Katherine. 2003, Comfort Theory And Practice: A Vision For Holistic Health Care And Research : New York: Spinger Publishing Company.

Kotler, Philip .2003. Marketing Management. New Jersey: Prentice Hall.

2000, Marketing Management : Analysis Planning Implemebtation and Control, Millenium Edition, Englewood Cliffs, New Jersey : Prentice Hall, Inc.

Kotler dan Amstrong. 2001. Prinsip - prinsip Pemasaran . Jilid 1 dan 2.Edisi 12. Jakarta: Erlangga

2008, Prinsip - prinsip Pemasaran, Jilid 1, Erlangga, Jakarta

Lupiyoadi, Rambat, 2001, Manajemen Pemasaran Jasa : Teori dan Praktik, Penerbit Salemba Empat, Edisi Pertama, Jakarta.

Rangkuti, Freddy .2003. Riset Pemasaran. Jakarta: Gramedia Pustaka Ulama 
Santono, Singgih dan Tjiptono, Fandy, 2001. Riset Pemasaran: Konsep dan Aplikasi dengan SPSS, Edisi Pertama, Jakarta: Alex Media Komputindo

Schiffman dan Kanuk. 2000. Perilaku konsumen. Edisi 7. Jakarta: Indeks

Sugiyono, 1994, Statistik Untuk Penelitian, Alfabeta, Bandung.

Sumarwan, Ujang. (2003). “ Perilaku Konsumen “. Penerbit Ghalia Indonesia, Jakarta

Yazid. 1999, Pemasaran Jasa, Konsep dan Implementasi Yogyakarta : Fakultas Ekonomi UII

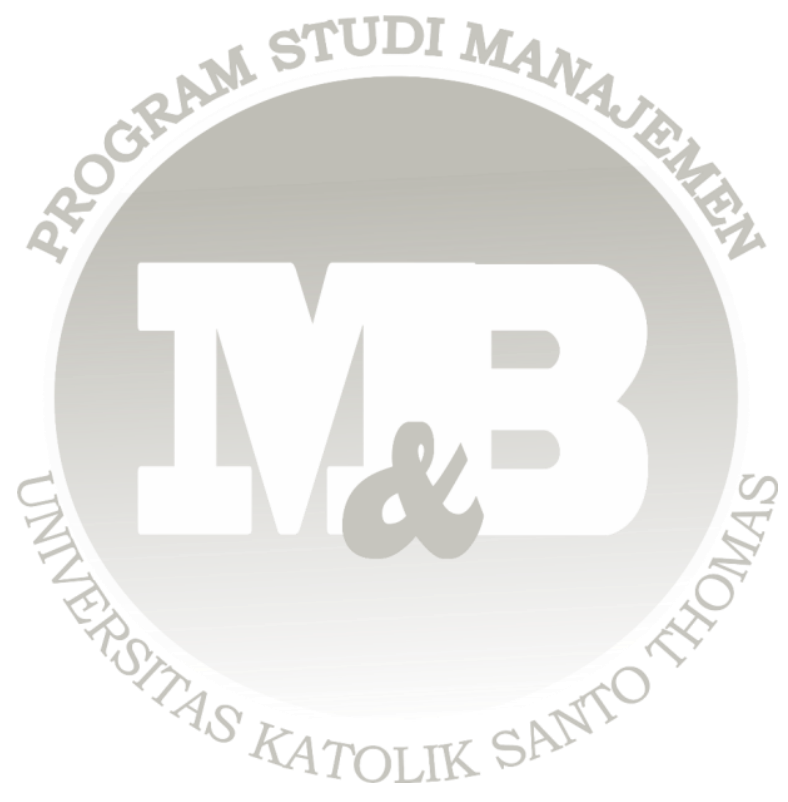

